\title{
Leadership and Management in the 21st Century Organizations:
}

\author{
A Practical Approach \\ Victor E. Dike ${ }^{1 *}$, Ken Odiwe ${ }^{2} \&$ Donatus M. Ehujor ${ }^{3}$ \\ ${ }^{1}$ Founder and CEO, Center for Social Justice and Human Development (CSJHD), Sacramento, \\ California, USA \\ ${ }^{2}$ Founder and CEO, Waterstone Management, Vallejo, California, USA \\ ${ }^{3}$ Computer Support Coordinator, San Francisco Bay Area Rapid Transit District (BART), Oakland, \\ California, USA \\ *Victor E. Dike, vdike@cwnet.com
}

\begin{abstract}
This article explores the place of leadership and management in the 21st century businesses and organizations, the role of leaders and managers, leadership styles as well as their levels of efficacy. It also investigates the attributes of an effective leader and manager, differentiates the concepts of leadership and management, leadership and management decision-making and problem-solving processes, and strategies for effective delegation of authorities to followers. This article argues that to function effectively and efficiently in today's new economy, every organization needs effective leaders and managers as well as competent and reliable followers. It also posits that the place of leadership and management in today's organizations are changing because, among other forces, the extreme competition among businesses in the new global economy, the emerging technologies, and globalization spurred by the Internet. The seemingly uncertainty in today's organizations are putting undue pressures on leaders and managers to adopt practical approach to leadership and management to motivate their followers to enhance their performance, share the visions and missions of the organizations so as to realize their set objectives. This article argues that what makes effective leadership and management in the rapidly changing 21st century organizations include their personality and style of leadership, passion and values, decision-making and problem-solving process as well as their expectations and levels of relationship with their followers. Leaders and managers require a practical approach to leadership and management to substantially influence and motivate their followers to enhance their performance to achieve set organizational objectives.
\end{abstract}

\section{Keywords}

leadership and management, leadership styles, followership, delegation, authority, the 21st century organizations, practical approach 


\section{Introduction}

Debates on the place of leadership and management in organizations have been on-going for decades and gurus in the field have observed that the basic principles and practices of leadership and management have not changed significantly over the years. However, they are becoming much more complex because of the nature of the 21st century organizations and the dynamics of the new global economy (Drucker, 2001, 2006; Rose, 2008; Trilling \& Fadel, 2009). Today’s leaders and managers, therefore, must behave differently as they need to acquire the essential practical skills and knowledge to thrive in the knowledge-driven 21st century global economy. For instance, they need to become better listeners and skilled change agents who can provoke persuasive reasons to get the followers to support their agenda. In addition, leaders and managers have to become great team players and relationship builders (Sadmann \& Vandenberg, 1995) as well as create motivating work environment to enhance workers' productivity.

It has also been observed that developing a 21st century business organization requires leaders and managers who are capable of making quick and effective decisions, learn to utilize the powers of emerging technologies and social media to effectively and efficiently communicate and coordinate actions (Drucker, 2001; Drucker, 2006; Trilling \& Fadel, 2009). They need to become aware of global politics in the world connected by the Internet and globalization, become more innovative and "create a sense of urgency, make decisions, and act” decisively (Rose, 2008). As Drucker (2006) has aptly observed, executive should first effectively manage themselves before they can possibly be expected to manage their co-workers and followers. Therefore, "The effectiveness of a modern society and its ability to perform-perhaps even its ability to survive-depend increasingly on the effectiveness of the people who work as executive in the organizations” (Drucker, 2006).

The 21st Century-what is it and when did the period begin? It is tempting to answer this question specifically. But the term "21st Century" is said to be elusive as it is difficult to describe or define because many writers have described it variedly. The 21st century—or the new millennium—said to be a period of transformations and changes has witnessed one of the most dramatic technological revolutions in human history after the industrial revolution. In The Meaning of the 21st Century, James Martin (2006) has described the 21st century as an era that has changed everything we do: the way we communicate and way we work. It is a period of technological revolution that centers on the computers, information, and communication as well as multimedia technologies. It is interpreted as the age of knowledge or information age that has come with tremendous challenges: extreme poverty, social violent, pandemic AIDS, water shortages, among others. It has also a period of transition and change that find solutions to the biggest challenges facing humanity (Martin, 2006). One has to possess certain skills and competencies to function effectively at this time of technological revolution (Trilling \& Fadel, 2009).

The 21st century was said to have "began on January 1, 2001 and will end on December 31, 2100" (United States Naval Observatory—http://aa.usno.navy.mil/faq/docs/millennium.php; also see Royal Published by SCHOLINK INC. 
Observatory Greenwich-http://www.rmg.co.uk/explore/astronomy-and-time/time-facts/faqs/newmillennium-where-when-wuhy). Meanwhile, in Management Challenges for the 21st Century, Drucker (2001) has discussed the profound social and economic changes and the new realities occurring today. For Peter F. Drucker, it is a period of "Profound Transition—and the changes are more radical perhaps than even those that ushered in the "Second Industrial Revolution" of the middle of the 19th century or the structural changes triggered by the Great Depression and the Second World War”. As Drucker (2001) has observed, the 21st century is a period of "information challenges" (p. 95) and increase in "productivity” for the "knowledge worker” (Drucker, 2001).

Leadership and Education in the 21st century Organizations: The 21st century organization needs "21st century education program” (Trilling \& Fadel, 2009), and education leaders at all levels must acquire the skills and knowledge to lead the stakeholders to adopt the 21st century teaching and learning methods to empower students (future leaders) with 21st century knowledge and skills (Trilling \& Fadel, 2009). This is because no matter the part of the world in which they live, students are connected with others "around the globe" (Trilling \& Fadel, 2009) via the Internet, social media and other emerging information technologies. The role of leaders and managers in the 21st century organizations is, therefore, becoming much more cumbersome because of globalization of education, politics and the dynamics of global business practices. Those who occupy these positions are expected to become conversant with leadership and management theories, principles and practices as they are component parts of social and economic development process (Drucker, 2006). Those theories, when appropriately applied in daily practice, can preserve the protocols and guide leaders and managers in smooth running of the 21st century organizations.

The dilemma of leadership and management has become complex problem in the 21st century organizations as they are confronted with the issues of doing things right no matter how tough they might be (Drucker, 1996; Drucker, 2001). Although leadership is not all about style, leaders and managers must choose from the various leadership styles to effectively lead and manage the 21st century organizations. Leadership is about character, taking responsibility, decision-making, and solving complex problem. So, leaders and managers in the 21st century organizations are expected to possess the capability and competence to design and implement appropriate interventions as problems arise (Stodgill, 1974; Parsons, 2015).

As Drucker (2001) has noted, "A great many of the individual knowledge workers to be affected by the challenges" of the 21st century "will be employees of business or working with business". So, the leader should be imbued with kindness and "social intelligence" (Goleman, 2007) to connect and build and enduring relationship with the followers and make work environment a better place to be. The challenges of the 21st affect all organizations and societies today. This article is expected to contribute to the basic understanding of the concepts of business and organizational management. The authors are hopeful that it will add new insights into the diverse and dynamic field of leadership and management and enhance people's knowledge and skills to lead and manage the 21st century organizations. 
The 21st century: promises and dangers: The 21st century is full of promises and dangers (OECD, 1998). For instance, the emerging technologies of the time are helping societies to realize their economic and social objectives (leading to innovations and creativity, bringing democracies to societies ruled by despotism, and press freedom, et cetera) and thus overcome some of the challenges facing them. The 21st century has also brought with it some social and economic uncertainties such are the unprecedented social crisis, riots and turmoil's, religious extremists (onslaught by al-Qaeda ISIS, Boko Haram, et cetera), global financial crisis and high youth unemployment that occur in some quarters (The Economist, 2012). The new era can, therefore, be described as a mixed baggage.

\section{Research Methods}

Information for this descriptive article was derived from the review of pertinent literature in the field of leadership and management. In other words, the primary method of this article was an extensive review of available related literature for an in-depth analysis of the issues in discourse.

\subsection{Problem Statement}

Debates about the place of leadership and management in organizations have been on-going for decades, but they are much more compelling in the 21st century. To survive in the new global economy leaders and managers need to adopt leadership and management styles that will fit into the 21st century work environment.

\subsection{Research Questions}

This article focuses on the following questions: What are the roles of leaders and managers in the 21st century organizations? What leadership and management styles are appropriate in today's organizations? How can leaders and managers motivate their followers to achieve their objectives in the new work environment?

\subsection{Leadership and Management: An Overview Leadership}

Numerous journal articles and books have been written on leadership and management by both classic and contemporary writers (Deming, 2000; Drucker, 2006; Juran, 2003; Stodgill, 1974; Kotter, 2008; Bennis, 2009). That goes to say that the issue in discourse is not new. The aim of this article, as noted earlier, is to add new insights of practical approach to the issues of leadership and management. Meanwhile, management for workers' high quality performance has undergone drastic transformation because of cut-throat competition and other forces in the new global economy. In Out of the Crisis (2000), which was originally published in 1982, W. Edwards Deming, who was one of the management gurus, presented fourteen major principles managers need to adopt in order to considerably improve the effectiveness and efficiency of their businesses or organizations. Among the principles are for management to "Create constancy of purpose" and "Institute training on the job". Leadership can be said to be about compassion and taking care of people. It is pertinent to note that a good leader act by force of Will and conviction to move his or her entity into the forefront of other organizations.

Like Deming (2000), another management guru, Joseph M. Juran (2003), in one of his many highly Published by SCHOLINK INC. 
acclaimed books, Juran On Leadership For Quality: An Executive Handbook, presented to top-level managers with field-tested medicine to effectively lead their organizations on their pursuit for higher quality products and services. Juran (2003) maintained that "quality improvement is needed for both kinds of quality: product features and from deficiencies". He also noted that "to keep costs competitive, companies must continually reduce the level of product and process deficiencies” (Juran, 2003).

Leadership can take place between a leader and a follower, a leader and a group of individuals, a local community or a global society. For Kotter (2008), being a leader is more than being in a position of authority; it encompasses accountability and responsibility. A leader is proactive in tackling issues; he or she does not wait for a problem to erupt. In addition, "good leaders recognize and reward success" (Kotter, 2008).

Before delving further into the issue of leadership and management, it is imperative to make certain what a "leader" is. The definition of a leader is as diverse as the myriad of books and articles written on the concept. The leadership guru, R. M. Stodgill, cannot put it any better when he observed that "There are almost as many definitions of leadership [and management] as there are persons who have attempted to define the concept" (Stodgill, 1974). This is because each writer has defined leadership and management from their own perspectives. No matter the angle from which the definition of leadership is viewed, a leader is one who exerts unusual influence and considerable power. According to McFarland (1969), a leader "is one who makes things happen that would not happen otherwise. If the leader causes changes that he intended, he has exercised power, but if the leader causes changes that he did not intend or want, he has exercised influence, but not power" (MacFarland, 1969; also see Kofele-Kale, 1976).

Hook (1943) shares a similar view as McFarland (1969) about leadership. In his work, The Hero in History, Hook (1943) has depicted a heroic leader as one who makes things happen that ordinarily would not have happened. "The hero in history", he observed, "is the individual to whom we can justifiably attribute preponderant influence in determining an issue or event whose consequences would have been profoundly different if he had not acted as he did". The hero is "an event-making individual who re-determines the course of history" (Hook, 1943). Students of leadership would share the views of Hook (1943) and McFarland (1969), that the prerequisites of leadership are influence and power. Any person who is endowed with these qualities in the context of a group, community or nation has, therefore, the personality of a leader (Kofele-Kale, 1976). Toward that, Henry Kissinger (US Secretary of State in Nixon Administration) pointed out in one of his famous speeches that a leader has the power to invoke the "alchemy of great vision". This, in other words, means that a leader should possess the power or influence of transforming something common into something precious.

Leaders have duties too. John Gardner (1978) has pointed out that the task of leaders is to help societies "understand the problems that all must face, to aid in the setting of goals and priorities, to work with others in finding paths to those goals chosen, maintaining public morale, and motivation and nurturing a workable level of public unity” (Gardner, 1978). Good leaders and managers (or executives) of Published by SCHOLINK INC. 
organizations, according to Drucker (1996), should know the right things to do; know how to do them; and how to do them effectively.

As noted earlier, leaders must activate existing institutions in pursuit of the society's goals or, when necessary, help redesign institutions to achieve that result. Leaders must also help people know how they can be at their best “...with malice toward none, with charity for all...” (Gardner, 1978). In a free society leaders perform these functions within a framework of constraints, including an uncorrupted electoral process, the rule of law, institutional checks and balances, and a free press.

In On Becoming a Leader, Warren Bennis (2009) observed that "all leaders have four essential competencies: they are able to engage others by creating shared meaning; they have a vision, and they can persuade others to make that vision their own". Warren Bennis added that "all authentic leaders have a distinctive voice-a purpose, self-confidence, and a sense of self... All true leaders have integrity—a strong moral compass". In addition, "leadership is always about character. They have competence—or adaptive capacity". This, according Warren Bennis, "is what allows leaders to respond quickly and intelligently to relentless change” in organizations (Bennis, 2009).

For Peter F. Drucker, "leadership is not magnetic personality — that can just as well be a glib tongue. It is not "making friends and influencing people-that is flattering. It has been noted that leadership is lifting a person's vision to higher sights, the raising of a person's performance to a higher standard, and the building of a personality beyond its normal limitations” (Drucker, 1993; also see Salman, 2009). How effective a leader becomes depends on what the behavior of the leader and what happens inside the leader's mind. This is because, as Dan Siegel (2010) has observed: "The human mind...regulates the flow of energy and information".

An effective leader is, therefore, said to be a good listener—one who consults widely before taking a decision. It has also been observed that effective leaders have three traits: a vision for the future of the organization that he or she leads; trust of colleagues and coworkers, and excellent communication skills. As John Powell has observed, "communication works for those who work at it" (as cited in Patterson, Grenny, McMillan, \& Switzler, 2003). In addition, perfect practice of communication makes it perfect. According to Dean Rusk (U.S. Secretary of State for President John F. Kennedy in Vietnam War), “One of the best ways to persuade others is you're your ears - by listening to them” (as cited in Patterson et al., 2003). A leader is also a manager. But, not all leaders are good managers and not all managers are good leaders. A person can be good at one but horrible at the other (Kotter, 2008).

\section{Management}

Management has been defined as activities required in designing, organizing, encouraging, and controlling personnel and operational resources needed to achieve organizational outcomes (Kotter, 2008). As Senge (2006) has observed, "When managers are committed to growing people in order to grow the enterprise or committed to utilizing conversation as the core process for change, their practices reflect insights into human nature-our innate desire to grow as human beings and to be in 
relationship with one another”.

Managers are known to focus on daily task completion in organizations. They do the heavy daily lifting or get the job done. Their duties include making work schedules, time cards, audits, and other staffing duties (Kotter, 2008; Parsons, 2015). Effective managers are skilled in coordinating and motivating employees, maintaining a safe work environment, and improving workers morale and productivity. Managers must have the energy and skills to meet the daily challenges of their duties (see Parsons, 2015).

Other scholars have noted that leadership and management, although similar, are two different concepts that are often used interchangeably (Drucker, 2006; Parsons, 2015; Kotter, 2008). For Kotter (2008), "Management is about coping with complexity" while "Leadership by contrast is about coping with change" (see Gallaos, 2008). Drucker (2006) has noted that management is about managing others.

To effectively and efficiently run the 21st century organizations, good leaders and managers are imperative. As noted, leadership is an individual's ability to influence others. Therefore, in contrasting management with leadership, Drucker (2009), in Essential Drucker, has noted that "Management is doing things right; leadership is doing the right things”. Warren Bennis (2000), in Managing the Dream, has observed that "Managers are necessary; [and] leaders are essential...Leadership is of the spirit, compounded by personality and vision...Management is of the mind, more a matter of accurate calculation, statistics, methods, timetables and routine” (Bennis, 2000).

Good leaders and managers will always strive to be the best they can possibly be for their organizations by accepting additional responsibilities to become even better, no matter the limitations imposed on them by some of their followers. Contrary to some people that perceive leadership as a title or a position loaded with prestige, we perceive leadership as an opportunity to leave the world or an organization a better place than the leader found it.

Despite the challenges, leadership is all about making a difference in lives of others; it is about collaborating with others to enable them fulfil their ambition; it is about stimulating creativity-bringing out the best in others. Leadership is about solving problems as well as transforming what appears an impossible task into an anthill. That takes us to leadership style.

\subsection{Leadership Styles: Brief Review}

As in leadership and management, several books and academic articles have been written on styles of leadership and their levels of efficacy (Bass, B. \& Bass, R., 2008; Lewin, Lippit, \& White, 1939; Cherry, 2006). A style of leadership denotes a leader's distinctive behaviors when leading, inspiring, guiding, and managing a group of individuals. Experts have noted that there is no one single best leadership style because each one is only as good as the circumstance in which the leader finds him or herself. Therefore, the style adopted by a leader depends on several variables, including his or her background, passion and vision, personality values and expectations from their followers. As Isaac Asimov was reported to have said, "If a man has any greatness in him, it comes to light not in a flamboyant hour but in the ledger of his daily work".

Published by SCHOLINK INC. 
It is, therefore, imperative to emphasize at the onset that some of the leadership styles discussed in this article can fit into the 21st century work environment, while others will not. This is because a leader can be autocratic, democratic, or Laissez-faire. In this article the discussion of these styles will be brief and will not follow any particular order.

\subsection{Autocratic}

Autocratic leadership is said to stress obedience, loyalty, strict adherence to roles (Bass, B. \& Bass, R., 2008; Lewin, Lippit, \& White, 1939; Parsons, 2015). The leaders who espouse this leadership style make and enforce the rules. In other words, they ensure that the decisions made are carried out. One of the benefits of autocratic leadership is their ability to develop reliable and devoted followers as well as act as the principal authority in establishing and maintaining order (Bass, B. \& Bass, R., 2008; Parsons, 2015). To achieve their purpose autocratic leaders utilize centralized decision making process without cognizant of the opinions of the followers (see Parsons, 2015).

Although authoritarian style of leadership may work well in a crisis period when decisions-making to resolve problems are needed immediately, it is unlikely to be effective in the knowledge-driven 21st century organizations. Therefore, autocratic style of leadership could be a preferred approach under an emergency situation, when there is an impasse, when everyone else is reluctant to take responsibility, when decisions need to be reached quickly, or when authority is being taken for granted (Lewin et al., 1939).

\subsection{Bureaucratic}

Bureaucratic style of leadership is somewhat related to the autocratic style of leadership. However, bureaucratic leader's decision-making process hinges on organizational policies, rules, and procedures established by the top-level administrative officers in organizations (Bass, B. \& Bass, R., 2008). They are inflexible as the leader follows what is in the book when making decisions with little or no in-puts from the followers who are expected to obey the orders (see Parsons, 2015).

\subsection{Democratic}

In a democratic style of leadership the leader is more participatory as members of organizations are given the opportunity to air their opinions or perceptions (Cherry, 2006). A democratic leader is therefore said to offer guidance to the followers as the leader allows them to participate in decision-making process (Mosely \& Patrick, 2011). The leader is also said to be disposed of making the followers to believe that they are important parts of the decision-making process. This psychology helps to foster employees' commitment to the objectives of the organization or group (Bass, B. \& Bass, R., 2008).

Additionally, the leader is said to be considerate, consultative, participative and employee-centered. The leader is concerned about the maintenance of good working relations; the leaders is supportive and moves toward facilitating interaction, good personal relationship and group decision-making process (Bass, B. \& Bass, R., 2008). This leadership style appears common in the 21st century organizations where collaborations and teamwork are encouraged.

Published by SCHOLINK INC. 


\subsection{Laissez-Faire}

The leaders and managers espousing laissez-fair leadership style are likely to defer daily decision-making to their employees (Parsons, 2015; Lewin, Lippit, \& White, 1939). And the employees are expected to adopt the existing policies and rules without question. The down side is that those who work under such a leader are said to be less productive with low levels of job satisfaction. However, laissez-faire (or the delegating style) leadership is said to be effective in conditions where the followers are highly skilled, motivated, and capable of working without close supervision (Parson, 2015).

As noted, this leadership style does not seem to be effective in situations where group members lack the knowledge or experience to complete tasks and make decisions (Lewin et al., 1939). As Bossidy, Charan, and Burck (2008) have aptly observed, "there is enormous difference between leading an organization and presiding over it. The leader who boasts of [his or] her hands-offs style or puts [his or] her faith in empowerment is not dealing with the issues of the day".

\subsection{Participative}

Participative leadership style, which is said to be similar to democratic leadership, encourages the followers to participate in decision-making process (Parson, 2015). However, the leader maintains the final opinion over the outcome of the decision-making process (Lewin et al., 1939; Cherry, 2006). Leaders practicing this style of leadership are known to guide responsible employees who like to solve problems (see Bass, B. \& Bass, R., 2008). Although it consumes more time, this leadership style involves everyone indecision-making process as employees discuss issues and reach a consensus (Bass, B. \& Bass, R., 2008). This leadership style appears effective in developing more elaborate and comprehensive organizational plan (Lewin et al., 1939).

\subsection{Transactional}

Transactional leadership, also known as managerial leadership (Bass, B., 1985; Bass, B. \& Bass, R., 2008; Burns, 1978), focuses on supervision, organization and group performance. This leadership style sees the leader-follower relationship as a transaction (Bass, B., 1985; Bass, B. \& Bass, R., 2008). This means that by accepting a position as a member of the group, the followers have agreed to obey the leader. In this style of leadership the leader or manager sets the goals for employees to follow because the main objective is to maintain workflow with the established company policies and protocols.

In Leadership, Burns (1978) perceived transactional leadership style as those leaders who are addicted to quid pro quo-“If you scratch my back, I will scratch yours” (see Banks, 2008). One of the main benefits of this style of leadership is that it creates clearly defined roles (Bass, B. \& Bass, R., 2008). Put differently, the followers are aware of what they are expected to do and what they will be getting in return for completing the assigned tasks.

It also allows the leaders to offer a great deal of supervision and direction when needed. The followers are motivated to perform well in order to receive the rewards (Burns, 1978). One of the disadvantages is that it is likely to suffocate creativity (Bass, B., 1985). Transactional leadership appears common in the 21st century organizations as its main objective is to get done with the routine work in the Published by SCHOLINK INC. 
organization, provide the people the services they need, or "getting things done through people" and reward them for performing (Northouse, 2007) their duties.

\subsection{Transformative}

Transformative leaders are those who have a vision to mobilize people to action (Burns, 1978; also see Banks, 2008). The leader transforms its team and influences the members to become better at what they do as well as inspires change in the organization. He or she has goal, insight, and create ways to achieve that goal (Bass, B. \& Bass, R., 2008). Transformational leadership style was said to have been described first in the late 1970s and later expanded upon by researcher Bernard M. Bass. Some of the main features of this style are the abilities of the leaders to motivate and inspire the followers and effect positive changes in the organization (Bass, B. \& Bass, R., 2008).

Transformational leadership is therefore often recognized as an effective style. This is perhaps because transformational leaders are inclined to be "emotionally intelligent, energetic, and passionate" (Bass, B. \& Bass, R., 2008). However, they are not only faithful in helping the group to achieve its objectives; and they help group members fulfill their full potential (Bass, B. \& Bass, R., 2008; Chrislip \& Larson, 1995). Transformative leadership appears to fit well in the ever-changing 21st century organizations and their work environments. This takes us to followership and leadership.

\subsection{Followership and Leadership}

There will be no leadership without followership. Put differently, every coin has two faces. According to McCallum (2013), followership is the other side of leadership. It has been observed that followership is an active interpersonal process of participating by following a leader or a manager. Good followers have certain qualities, including good judgement, knowing the difference between a directive that the leader gives and how to proceed (McCallum, 2013). Good followers are said to have good work ethic as majority of them are "competent” at performing their tasks (Latour \& Rast, 2004; Cavell, 2007).

Honesty is an important trait of good followers (McCallum, 2013). They owe the leader an honest and forthright assessment of what the leader is trying to achieve; display loyalty to the organization and to the leader (Latour \& Rast, 2004). Good followers are known to be courageous in taking more responsibility (Hertig, 2010). They are said to be loyal to the enterprise and its goals as well as support the leader's decisions even when there are problems (interpersonal or otherwise) with the leader; and they are competent and dependable (Cavell, 2007). Although followers are expected to accept the guidance and direction of the leader, not all followers are effective followers. Those who are not loyal are inevitably a source of trouble to the organization and, of course, to the leader. Experience shows that a disobedient or passive follower is a clog in the wheel to the progress of the organization.

Good followers are great team players in the fullest sense of the concept and have good interpersonal skills (Lundin \& Lancaster, 1990). They have the knack in managing their egos as they always put them under control and work for the well-being of the organization. For McCallum (2013) good followers will not criticize the leader in public. From a practical approach they often resort to private dialogue or engage in "constructive conversation" to resolve any disagreement with the leader 
(Patterson, Grenny, McMillan, \& Switzler, 2002).

As Bjugstad, Thach, Thompson, and Morris (2006) have observed: "Without [loyal] followership, a leader at any level will fail to produce effective institutions". Good relationship between followers and leaders are imperative because "effort from both leaders and followers is required for effective change" (Mosley \& Patrick, 2011). The roles of leaders, managers, and followers resemble each other in 21st century organizations because it has been observed that "being an effective follower requires as much work as being an effective leader”. Behaviors that reflect effective leading, managing, and following complement each other as it requires "great leadership and management behaviors to establish and achieve organizational objectives” (Parsons, 2015). Effective followers share the mission and visions of their organizations and help the leader to achieve the set objectives. This takes us to the power of delegation of authority to followers.

\subsection{Leadership and Delegation of Authority}

Numerous academic articles and books have also been written on leadership and delegation of authority to others (Kouzes \& Posner, 1995; Bossidy, Charan, \& Burck, 2008). Delegation of authority is one of the essential functions of leaders and managers in the 21st century organizations. While ultimate responsibility cannot be relinquished by the leaders, delegation of authority carries with it the imposition of a measure of responsibility. That is where the delegator-the leader or manager-must listen properly and communicate clearly so as to ensure that authority is delegated to the competent and loyal followers. An effective organization is a product of collective leadership and good team effort because leadership in every organization is everyone’s business (Kouzes \& Posner, 1995).

The leader transfers authority to a competent follower to perform some of his or her duties in selected situations. As noted before, the leader or manager remains answerable for the result of the work delegated (Parsons, 2015). Due to the complexity of the position, leaders and managers cannot perform all their functions without utilizing the principles of delegation in decision-making and problem-solving process (Bossidy et al., 2008). That is to say that leaders and managers are encumbered by many challenges that they have to assign some of their less pressing functions (those that do not really need their attention) to their followers or colleagues (Kouzes \& Posner, 1995).

When a leader or a manager delegates authority he or she empowers others. But a leader does not delegate functions that require "detailed proof" or explanation like the "theory of relativity", which "took Albert Einstein more than a decade to develop” (Bossidy et al., 2008). However, according to Kouzes and Posner (1995), the delegator must "Make sure [that the] delegated tasks are relevant”" to empower the person and place him or her in a position of responsibility.

Delegation of authority must not be done haphazardly, but effectively (Kurtz, 2007). For leaders and managers to properly delegate authorities to followers' they must understand the delegation process, pitfalls of delegation of authority, and acquire delegation skills (see Parsons, 2015). But no matter the pitfalls in delegation (such as under delegation, over delegation, or improper delegation) a leaders should not hesitate to delegate because the benefits of delegation are myriad. 
The unrelenting changes in today's organizations and the increasing demand on leaders and managers (as noted earlier) in the 21st century organizations compels them to shift some of their lower-level functions (directly or indirectly) to their followers. This allows them time and frees other resources to focus on more pressing issues (see Parsons, 2015). Delegation of authority is good for the leader, the manager, and the follower as well as for the organization. It enables the leader to help others (followers) to grow, develop their leadership skills, and work towards achieving the objectives of their organizations. As Kouzes and Posner (1995) have aptly noted, "Success in leadership, success in business, and success in life [even success at home] has been, is now, and will continue to be a function of how well people work and play together".

\subsection{Leadership and Management in the 21st Century Organizations}

As we have noted at the onset, leadership in the 21st century organizations is different from what is used to be in the $19^{\text {th }}$ and $20^{\text {th }}$ century. For Sandmann and Vandenberg (December 1995), "Leadership development for the 21st century requires a change in personal practice, conceptual thinking, and organizational application”. Due to the dynamic nature of the 21st century organizations, everything is changing, including the role of human resources. The task force created in 1994 under the tutelage of Michigan State University Extension noted that the 21st century leadership and its development is different from that of the $20^{\text {th }}$ century. The scholars have also observed that "leadership development for the 21st century is holistic: it is centered in groups or organizations, rather than individuals, and engage the group in heart, mind, and energy” (Sandmann \& Vandenberg, December, 1995). Leading in today's knowledge-driven and highly competitive business environment requires practical experience and exemplary leadership who can motivate followers to achieve organizational objectives as they work harder to create value added in the organizations.

As noted earlier, the ubiquitous social media and the emerging technologies (Prensky, October, 2001) have changed the way leaders and managers tackle issues in businesses and organizations as well as how they lead and manage their followers (Kaplan, 2009). There are, therefore, essential career skills that are needed to function effectively in the 21st century economy. Most of the workers in today's organizations are said to be "digital natives" (those who grew up with the emerging technologies) as opposed to the "digital immigrants" (those born before the advent of modern technologies and are learning to use them) (Prensky, October, 2001). "Digital immigrants” populated business and public organizations during the centuries before the 21st century where "digital natives" are the majority (Prensky, 2001).

For leaders to lead and manage their followers in this Culture of Change (Fullan, 2007), and in order for them to assist their followers to acquire the essential 21st century skills that will enable their workers to achieve the goals of their organizations, they must possess the needed skills, including being technologically savvy. Leaders and managers must also be cognizant of the ways they are perceived by the public, because how they are perceived may affect their reputation, that of the organization, and their effectiveness in managing their organizations.

Published by SCHOLINK INC. 


\subsection{Characteristics of the 21st Century Organization}

As it has been noted, the characteristics of the 21st Century organizations and their leadership framework are unique (Sandmann \& Vandenberg, 1995). As it has been observed, the 21st century has its challenges as it has changed the foundations of today's societies and organizations (Friedman, 2007). The world that is now inter-related has a "global financial and economic ecosystem" (Trilling \& Fadel, 2009). As result, what affects one part of the world will affect the entire global economic system. The late 2008 world financial crisis and the "Arab spring" (The Economist, 2012) are typical examples. Although 2008 world financial crisis started in the West, the ripple effect crippled the economies of the developing nations with economic recession, social and political instability (Lardy, 2012; Trilling \& Fadel, 2009). The same can be said of the "Arab spring" that rattled the entire Middle East leaving the political leaders to grapple with solutions to the grassroots revolution.

For Stevenson and McGrath (2004), the structure of the 21st Century organizations is more complex with distant boundaries, reliance on emerging information and communication technologies. This brought changes in the way people relate to one another, how they communicate as well as changes in career and life skills. To be successful in today's work place, one has to possess the essential skills and knowledge, particularly "Information literacy; Media Literacy; and Information and communication technology (ICT) literacy” (Trilling \& Fadel, 2009).

It is also worthy of mention that there are virtual organizations in the 21st century, and as such, social and organization boundaries are somewhat blurred (Stevenson \& McGrath, 2004). It has, therefore, been observed that virtual organizations need leaders with the expertise and practical skills to manage them. Virtual leaders of the 21st century organizations are said to "be brighter than" their counterparts in the $20^{\text {th }}$ century" because they must be "multi-task within a complex network of loosely knit organizational entities” (Stevenson \& McGrath, 2004; Pauleen, 2003; Bell \& Kozlowski, 2002). Their complexity is said to be an additional burden that place greater demands on leaders and mangers.

For Yeramayan (2014), successful 21st century organizations have peculiar traits. Accordingly, the21st Century leaders are involved in relentless innovation; they are purposeful; they have passion for growth; they have good customer relationship; and they are good at creating break-through performance environment (see Forbes, 2014). Therefore, to lead and grow a successful 21st century organization leaders or managers must determine what issues to focus their attention in order to compete effectively in the rapidly changing global economy (Yeramayan, 2014). Towards that, Jared Diamond has aptly observed that "The crux of success or failure [in the 21st century business environment] is to know which core values to hold on to, and which to discard and replace when times change" (as cited in Trilling \& Fadel, 2009).

Given the unique situation in the 21st century, every society that wants to move ahead are planning and working on empowering their citizens with the skills and knowledge to enable them fit into the knowledge-driven new global economy. Those who are operating on $19^{\text {th }}$ and $20^{\text {th }}$ century system will not perform as well as those who have acquired the 21st century skills and knowledge (Trilling \& Fadel, 
2009; Miller, 2007). Since the global economy is rapidly changing, what worked in the $20^{\text {th }}$ century will hardly fit into the fast changing 21st century economy.

The emerging technologies in this era have expanded the responsibility and accountability of leaders and mangers in today's organizations. Perhaps, they have reduced their burden on efficiency and effectiveness in leading and managing their organizations (Drucker, 2001; Drucker, 2006; also see Trilling \& Fadel, 2009). They have also made managing projects, planning, executing, and evaluating them less cumbersome. Leaders, managers and followers in today's organizations are, therefore, gearing up to acquiring the essential skills and knowledge to enable them tackle the challenges of the economic time.

The emerging technologies can also have made a good number of people lonely in the madding crowd of the 21st century. Those who are technology savvy can spin out information to the world from their remote enclaves with the emerging technologies. According to Halvorson (2014), because human beings are profoundly social, connected and want to work together, managers need to constantly remind their employees that they are not working "alone". Halvorson (2014) has argued that this phrase (not working "alone”) will motivate your employees to perform at their optimal levels.

Education and the 21st century: changes have also been introduced in teaching and learning in the 21st century schools. The type of teaching and learning as well as standard of education in a society determines the level of its economic growth and the people's living standard (Miller, 2007). Adopting the 21st century teaching and learning methods will empower the youths with the knowledge and skills to compete effectively in today's technology-driven new global economy.

As noted earlier, the 21st has its challenges as much as it has provided solutions to its effects on organizations and the society as a whole. The challenges do not only affect how business leaders lead and manage their organizations, they affect how students learn and how teachers teach (Trilling \& Fadel, 2009). Students all over the globe will need plenty of practical exercises in using the 21st century skills (Trilling \& Fadel, 2009) such as "critical thinking and problem solving, computer and technology skills, communication and self-direction skills” (Trilling \& Fadel, 2009) in the 21st century work environment. Towards that, Trilling and Fadel (2009) have observed that some states in the United States and other advanced nation "have adopted a new set of education standards" to produce graduates with the knowledge and skills to compete effectively in the 21st century global economy. Like in other aspects of development, the developing nations are lagging behind in the technological race.

Today's leaders and managers must, therefore, be prepared to face the reality of the 21st century economy and work harder to develop the essential skills and knowledge to achieve their personal objectives as well as those of the organizations in which they work (Boyatzis, 2008). As noted earlier, digital and other emerging technologies are said to be making the jobs of leaders and managers a lot easier by "freeing up time" for them "to focus on the 21st century skills and other challenges" tossed-up by the century. For instance, the emerging technologies are helping them to build on-line Published by SCHOLINK INC. 
skills for collaboration, communication, and leadership, as well as for social relationships and cultural skills (Trilling \& Fadel, 2009).

However, for all these to be possible the educators must first be educated and motivated to face the challenges of the rapidly changing world (Darling-Hammond \& Brransford, 2005). This will enable the educators in the field to integrate emerging instructional technologies and the 21st century skills into their teaching and learning methods. Societies, particularly developing nations, should be prepared to undertake revolutionary changes in their teaching and learning methods (Tomlinson, Brimijoin, \& Narvaeez, 2008).

\section{Recommendation}

It is pertinent to note at the onset that the recommendations we have offered here are not definitive, but suggestive. Some scholars might have better recommendations given their experiences and perspectives. That said, leaders and managers should be consistent with their vision and passion as well as their methods of communication. This will enable them to connect with them, earn their trust and improve their productivity as well as to achieve their organizational objectives. We, therefore, argue that being consistent in their actions will enable them to put their employees or followers at ease and avoid them from second-guessing what to expect from their leaders and managers. Being transparent will also improve the leader's integrity. As every organization is striving to improve their employees' productivity, leaders and managers need to re-examine their management styles or practices to ensure that they align with their expectations from the followers.

Related to the above is the fact that some, if not most, leaders and managers do not understand the “mindset” of their followers (Dweck, 2007). That is why this paper is recommending that they need to adopt new techniques to know their followers experiences and perceptions about the organization in which they work. If the followers appreciate the leaders' leadership style and how they are being treated, their productivity and the bottom line of the organization are more likely to improve. It has been noted that disgruntled followers can kill the leader's character and stunt his or her vision. It is, therefore, recommended that leaders and managers of the 21st century organizations need to help their followers understand "the forces that shape their feelings, thoughts, and actions" (O’Brien, 2015), and learn to motivate and engage low performers while they embrace high performers.

The ability for leaders and managers to effectively lead and become innovative at the same time is more critical in today's 21st century organizations as the work environment is becoming much more complex and dynamic. To lead effectively leaders must, therefore, possess the art of persuasion and motivating others to perform more than they thought was impossible in their quest to achieve a common purpose. Also, it is recommended that leaders and managers must sharpen their creative potentials and acquire new innovative ideas to be able source the right solutions to social, political and economic issues facing their organizations or nations. One cannot become a great leader without increasing his or her creative potential and removing barriers to change. We, therefore, recommend that 
leaders and managers of the 21st century organization should be those who grew up in the digital age (Tapscott, 2009), and not the “digital immigrants” (Prensky, 2001).

It has been noted that our life experiences affect the way we react to event around us. It is, therefore, recommended that leadership development programs should incorporate mental training, social intelligence, and emphasis behavior and change in mindset. From the authors' practical experience, it is recommended that mindfulness should be a part of training strategy for leadership and personal development as well as a way to improve worker's productivity and their well-being. As noted, leaders and managers must also learn to clearly communicate their vision to their followers. This skills has been noted as one of the secrets to success as a leader in the 21st century organization (Trilling \& Fadel, 2009) because it is imperative for leaders to get the people to cooperate and support his or her agenda. Also, the leader must always take the followers "expectations into consideration" and learn to plan strategically, persuade, negotiate, and solicit their cooperation. The leader must understand the needs and goals of the followers and work toward helping them to actualize their ambition through delegation of meaningful responsibilities based on their capabilities, qualities and strengths to deliver.

Additionally, leaders and managers need to give their employees (workforce or followers) the tools to become more resilient— “ability to adapt to stress and adversity”. This is because according to Mark Murphy of the Leadership IQ, the 21st century organizations and its work environment is of full of "bumps in the road". Resilience will enable them to make it to happen to everyone. But the key to success as a leader is how quickly your employees "bounce back" and reenergize when they hit the unavoidable bumps in today's highly competitive and unstable work environment (Murphy, 2015).

\section{Summary and Concluding Remarks}

We have noted that there is no single definition of styles of leadership and management as the two concepts take many forms. We have also explored leadership and management styles, organizational structures and emphasized that the skills levels of the workers determine the leader's levels of productivity as well as the general productivity of the organization. We have noted that a leader is also a manager and vice-versa and that combining leader's and manager's competencies in the 21st century organizations will enable one to become an effective leader and manager in the uncertain new global economy.

Delegation of authority is one of the skills leaders use to empower their followers with crucial critical thinking and problem-solving skills to find solutions to organizational problems and enhance their roles in tackling social problems. Leaders and managers in the 21st century organizations must do things differently than those of the $19^{\text {th }}$ and $20^{\text {th }}$ century in order to effectively lead and succeed in the highly competitive global economy. They must be leaders and entrepreneurs who will ensure that their organizations can adapt and innovate in today's dynamic technologically-driven work environment (Perrin et al., 2010; Boyatzis, 2008).

Being conversant with the emerging technologies will enable leaders and managers of the 21st century Published by SCHOLINK INC. 
organizations to maintain active awareness of the dynamic of global political environment and apply practical solutions to personal problems to achieve organizational success (Perrin et al., 2010; Boyatzis, 2008). Effective leadership and management skills will impact positively on work environment. Today's leaders and managers must have the capability to build responsive interpersonal relationship with their followers, communicate effectively both in person and in writing, build a great team, and collaborate effectively with leaders and managers in other businesses and organizations (Goleman, 2007). They must lead by example, be flexible and transparent, have a vision, gain the trust of their followers so as to and help them to develop essential skills and capabilities through education and job training (Trilling \& Fadel, 2009). Leaders and managers in the 21st century organization must possess the skills to plan and implement effective interventions as problems arise. Delegation of authority to their followers is among the essential skills for leaders and managers to possess in today's work environment. The pace of change will accelerate faster than expected in the 21st century and executives of organizations across the globe should be prepared to respond accordingly.

The 2008 global economic and financial crises, which the former U.S. Federal Reserve Chairman, Ben Bernanke, quoted to have said was worse than the great depression (Worstall, 2014), provided leaders of organizations a glimpse of what life would be like if they fail to acquire the necessary skills to become creative and innovative. To be successful in the new global economy leaders and managers must continually develop their leadership skills to enable them understand themselves and those they lead. The 21st century leadership and management development programs should, therefore, focus on teaching future leaders and managers the essential skills. They should emphasize that humility, honesty, and integrity will translate into a positive work environment that will translate into workers' higher productivity, other things being equal.

\section{Final Discussion}

Drawing on pertinent theories we have emphasized that the leaders and managers in the 21st century organizations need to learn how to navigate through the complex and uncertain terrain and of today's highly competitive global economy. To achieve the objectives they must take their followers along with them by motivating and empowering them with the skills and knowledge to perform their duties and move the organization forward. In addition, they must understand that most of the skills that worked in the $19^{\text {th }}$ and $20^{\text {th }}$ century organizations will not be applicable in today's work environment. And that it requires effective strategies and flexible mindsets for leaders to lead in a Culture of Change (Fullan, 2007). Therefore, having a "growth mindset" (Dweck, 2007) can change the outcome of a leader's efforts.

Leaders and managers in the 21st century organizations need to have information or digital literacy skills, media literacy and information and communication technologies (ICT) skills and engage in environmental and socially responsible behavior for a healthy global economy. We have in this article combined the available pertinent leadership and management theories with our practical experiences to 
provide an instructive guide to the current and future leaders and managers of the 21st century organizations. To be successful in dealing with their followers and moving their organization forward, leaders and mangers need to learn to tap on their "emotional intelligence" (Goleman, 1998) and "social intelligence" (Goleman, 2007). Let's hope that the leaders and managers will push the right buttons in their organizations!

\section{References}

Bass, B. M. (1985). Leadership and Performance. New York: Free Press.

Bass, B. M., \& Bass, R. (2008). The Bass Handbook of Leadership: Theory, Research, and Managerial Applications. New York: Free Press.

Bell, B. S., \& Kozlowski, S. W. J. (2002). A typology of virtual teams: Implications for effective leadership. Group and Organization Management. Thousand Oaks, 24(1), 14-26.

Bennis, W. (2000). Managing the Dream: Reflections on Leadership and Change. Cambridge: Basic Books.

Bennis, W. (2009). On Becoming a Leader: The Leadership Classic (revised and updated). Cambridge: Basic Books.

Bienen, H. (1993). Leaders, Violence, and the Absence of Change in Africa. Political Science Quarterly.

Bjugstad, K., Thach, E. C., Thompson, K. J., \& Morris, A. (2006). A fresh look at followership: A model for matching followership and leadership styles. Journal of Behavior and Applied Management, 7(3), 304-319.

Bossidy, L., Charan, R., \& Burck, C. (2008). Execution: The Gap Nobody Knows. In Joann V. Gallos (Ed.), Business Leadership, A Jossey-Bass Reader (2nd ed.). San Francisco: John Wiley \& Sons, Inc.

Boyatzis, R. E. (2008). Competencies in the 21st Century. Journal of Management Development, 27(1), 5-12.

Burns, J. M. (1978). Leadership. New York: Harper \& Row.

Cherry, K. A. (2006). Leadership styles. Retrieved from http://psychology.about.com/od/leadership/ a/leadstyles.htm

Chrislip, D., \& Larson, C. E. (1995). Collaborative Leadership-How Citizens and Civic Leaders can make a difference. San Francisco: Jossey-Bass Publishers.

Darling-Hammond, L., \& Bransford, J. D. (2005). Preparing teachers for a changing world: What teachers should learn and be able to do. San Francisco: Jossey-Bass.

Davell, D. P. (2007). Leadership or followership: One or both? Healthcare Financial Management, 61(11), 142-144.

Deming, W. E. (2000). Out of the Crisis. Cambridge: The MIT Press. 
Drucker, P. F. (1996). The Executive in Action: Managing for Results, Innovation and Entrepreneurship, the Effective Executive (1st ed.). New York, N.Y: Harper Business.

Drucker, P. F. (2001). Management Challenges for the 21st Century. New York, N.Y: Harper Business.

Drucker, P. F. (2006). The Effective Executive: The Definitive Guide to Getting the Right Things Done. New York, N.Y: Harper Business.

Drucker, P. F. (2009). The Essential Drucker: Management; the Individual and Society. Collins Business Essentials.

Dweck, C. S. (2007). Mindset: The New Psychology of Success (Paperback). New York: Ballantine Books - an imprint of the Random House Publishing Group.

Frankena, W. K. (1963). Ethics. (2nd ed.). Prentice Hall, Inc.

Friedman, T. L. (2007). The world is flat 3.0: A brief history of the twenty-first century. New York: Picador.

Fullan, M. (2007). Leading in a culture of change (revised edition). San Francisco: Jossey-Bass.

Gardner, J. W. (1978). Morale (pp. 132-135). New York.

Goleman, D. (1998). Working with Emotional Intelligence. New York: Bantan Books.

Goleman, D. (2007). Social intelligence: The new science of human relationships. New York: Bantam Books.

Halvorson, H. G. (2014). Managers Can Motivate Employees with One Word. In Harvard Business Review.

Hertig, J. (2010). Followership: Nontraditional leadership roles for new practitioners. American Journal of Health-System Pharmacy, 67(17), 1412-1413.

Hook, S. (1943). The Hero in History: A study in Limitation and Possibilities. New York: The Humanities Press.

Juran, J. M. (2003). Juran On Leadership For Quality: An Executive Handbook. New York: Simon and Schuster.

Kaplan, R. S. (2009). Lead and Manage. Leadership Excellence, 26(10), 7-8.

Kofele-Kale, N. (1976). The Problem of Instrumental Leadership in Contemporary African Political Systems. Journal of Asian and African Studies, xiii.

Kotter, J. P. (2008). What Leaders Really Do. In J. V. Gallos(Ed), Business Leadership, A Jossey-Bass Reader (2nd ed.). San Francisco: John Wiley \& Sons, Inc.

Kouzes, J. M., \& Posner, B. Z. (1995). The Leadership Challenge: How to keep getting extraordinary things done in organizations. San Francisco: Jossey-Bass Publishers.

Kurtz, R. (2007). How to delegate effectively. In Bloomberg Business.

Lardy, N. R. (2012). Sustaining China's economic growth after the global financial crisis. Washington, DC: Peterson Institute for International Economics.

Lewin, K., Lippit, R., \& White, R. K. (1939). Patterns of aggressive behavior in experimentally created social climates. Journal of Social Psychology, 10, 271-301. 
Latour, S. M., \& Rast, V. J. (2004). Dynamic followership: The prerequisite for effective leadership. Air \& Space Power Journal, 18(4), 102-110.

Lundin, S. C., \& Lancaster, L. C. (1990). Beyond leadership...The Importance of Followership. The Futurist, 24(3), 18-22.

Murphy, M. (2015). Live Webinar: Making your workforce wore resilient. Leadership IQ Newsletter. Atlanta, GA. Retrieved from http://www.leadershipiq.com/collections/live- webinar-events/ products/live-webinar-making-your-workforce-more-resilient?mc_cid=a8a5bda7af\&mc_eid=f188 d7f634

Martins, J. (2006). The Meaning of the 21st Century. New York: Riverhead Penguin.

May, K. E. (1998). Work in the 21st Century: The Changing role of Human Resources. In Society for Industrial and Organizational Psychology. Retrieved from http//www.siop.org/tip/ backissues/tipjan 98/may.aspx

McCallum, J. S. (2013). Followership: The Other Side of Leadership. Ivey Business Journal, September/October. Retrieved from http://iveybusinessjournal.com/publication/followership-theother-side-of- leadership/

McFarland, A. S. (1969). Power and Leadership in Plural Systems. Stanford University Press.

Miller, R. (2007). Education and economic growth: From the 19th to the 21st century. San Jose, CA: Cisco Systems. Retrieved from http://www.rielmiller.com/images/Education-and-EconomicGrowth.pdf

Mosley, D. C., \& Patrick, D. K. (2011). Leadership and Followership: The dynamic process of building high performance cultures. Organization Development Journal, 29(2), 85-100.

O’Brien, J. (2015). The Production of Reality: Essays and Readings on Social Interaction (6th ed.). SAGE Publications, Inc.

OECD. (1998). 21st Century Technologies: Promises and Perils of a dynamic future. The organization for economic co-operation and development (OECD) Publications, printed in France.

Parsons, L. C. (2015). Leadership and Management for Every Nurse (2nd ed.). Nurses Continuing Education-CE Express Home Study.

Patterson, K., Grenny, J., McMillan, R., \& Switzer, A. (2002). Crucial Conversations: Tools for Talking when stakes are high. New York: McGraw-Hill.

Pauleen, D. J. (2003). Leadership in a global virtual team: An action learning approach. Leadership and Organization Development Journal, 24. Bradford.

Perrin, C., Daniels, S., Jefferson, C. K., Blauth, C., Marone, M., O’Sullivan, C., ... Moran, L. (2010). Developing the 21st-Century Leader: A multi-level analysis of global trends in leadership challenges and practices. Achieve Global, 2. Retrieved from http://www.achieveglobal.com/ resources/ files/AchieveGlobal_21st_Century _Leader_Report.pd

Prensky, M. (2001). Digital natives, digital immigrants. On the Horizon, 9(5). 
Rose, C. (2008). Leadership for the 21st Century. In Harvard Business School. The Global Business Summit.

Royal Observatory Greenwich. (2015). In Jump Up-When and where did the new Millennium officially start, and why.

Salman, Y. A. (2009). The Dynamics of Human Resources: A Journey into the Noble Practice of Managing Human Capital. Bloomington: iUniverse.

Sandmann, L. R., \& Vandenberg, L. (1995). A Framework for 21st Century Leadership. Journal of Extension, 6(33), 1-6.

Senge, P. M. (2006). The Fifth Discipline: The Art \& Practice of Learning Organization. New York: Currency Doubleday.

Siegel, D. J. (2010). Mindsight: The new science of personal transformation. New York, NY: Bantam Books.

Stevenson, W., \& McGrath, E. W. (2004). Differences between on-site and off-site teams: Manager perceptions. Team Performance Management, 10(5), 127. Bradford.

Stodgill, R. M. (1974). Handbook of Leadership: A Survey of Theory and Research (Hardcover). Free Press.

Tapscott, D. (2009). Grown up digital: How the net generation is changing your world. New York: McGraw-Hill.

Trilling, B., \& Fadel, C. (2009). 21st Century Skills: Learning for life in our times. San Francisco: John Wiley \& Sons, Inc.

Tomlinson, C. A., Brimijoin, K., \& Narvaez, L. (2008). The differentiated school: Making revolutionary changes in teaching and learning. Alexander, VA: ASCD.

The Economist. (2012). In Leaders' section—Egypt in peril.

United States Naval Observatory. (2015). In The 21st Century and the 3rd Millennium: When Did They Begin?

Worstall, T. (2014). Ben Bernanke: The 2008 Financial Crisis Was Worse Than The Great Depression. In Forbes.

Yeramyan, P. (2014). The six defining traits of the successful 21st century organization. In Forbes-leadership. Retrieved from http://www.forbes.com/sites/gapinternational/2014/09/03/thesix-defining- traits-of-the-successful21st-century organization/ 